(2) norden 



\section{Ekonomiska utsikter i Norden 2009}

Nordiska konjunkturgruppens redogörelse hösten 2008 
Ekonomiska utsikter i Norden 2009

TemaNord 2008:601

(C) Nordiska ministerrådet, Köpenhamn 2008

ISBN 978-92-893-1785-6

Tryck: Ekspressen Tryk \& Kopicenter

Upplaga: 0

Tryckt på miljövänligt papper som uppfyller kraven i den nordiska miljösvanemärkningen.

Publikationen kan beställas på www.norden.org/order. Fler publikationer på

www.norden.org/publikationer

Printed in Denmark

Nordiska ministerrådet

Store Strandstræde 18

DK-1255 Köpenhamn K

Telefon (+45) 33960200

Fax (+45) 33960202

\section{Nordiska rådet}

Store Strandstræde 18

DK-1255 Köpenhamn K

Telefon (+45) 33960400

Fax (+45) 33111870

www.norden.org

\section{Det nordiska samarbetet}

Det nordiska samarbetet är ett av världens mest omfattande regionala samarbeten. Det omfattar Danmark, Finland, Island, Norge och Sverige samt de självstyrande områdena Färöarna, Grönland och Åland.

Det nordiska samarbetet är politiskt, ekonomiskt och kulturellt förankrat och är en viktig partner i europeiskt och internationellt samarbete. Den nordiska gemenskapen arbetar för ett starkt Norden i ett starkt Europa.

Det nordiska samarbetet vill styrka nordiska och regionala intressen och värderingar i en global omvärld. Gemensamma värderingar länderna emellan bidrar till att stärka Nordens ställning som en av världens mest innovativa och konkurrenskraftiga regioner. 


\section{Innhold}

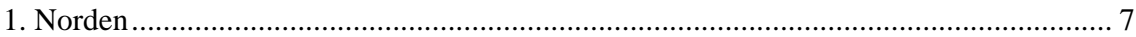

1.1 Utviklingen i internasjonal økonomi ........................................................... 7

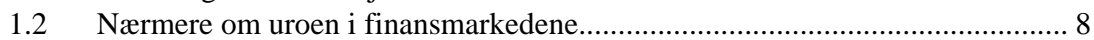

1.3 Den økonomiske utviklingen i Norden .......................................................... 9

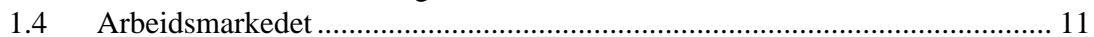

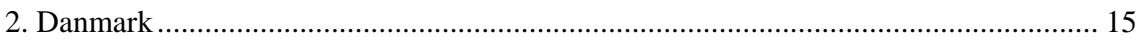

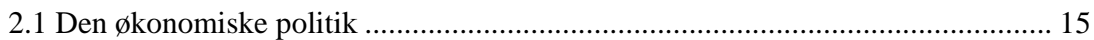

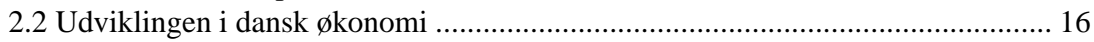

2.3 Udsigterne på mellemlangt sigt ........................................................................ 18

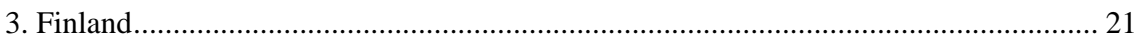

3.1 Den ekonomiska politiken.......................................................................... 21

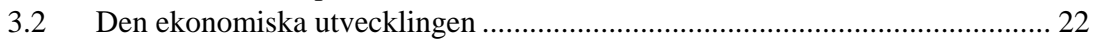

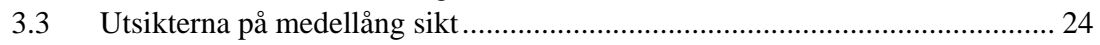

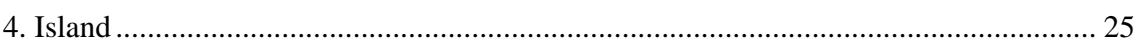

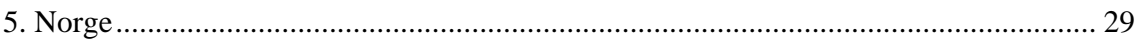

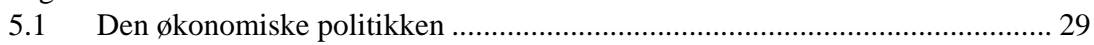

5.2 Den økonomiske utviklingen ...................................................................... 30

5.3 Utsiktene på mellomlang sikt.......................................................................... 32

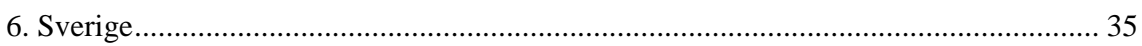

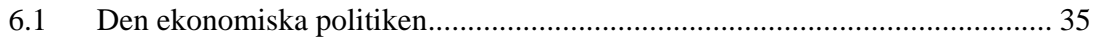

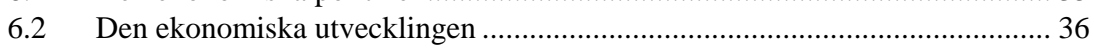

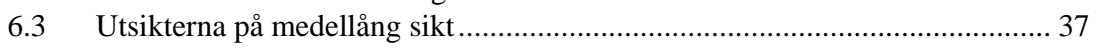





\section{Norden}

\subsection{Utviklingen i internasjonal økonomi}

Etter flere år med sterk oppgang i verdensøkonomien har veksten avtatt betydelig det siste året. Mens det i 2007 var en samlet vekst i verdensøkonomien på 5,0 pst., anslår IMF at veksten vil avta til 3,9 pst. i år og 3,0 pst. til neste år. Det er særlig tre utviklingstrekk som bidrar til avdempingen i veksten: (i) Fallende boligpriser i USA, og etter hvert også i flere andre OECD-land, (ii) uro i finansmarkedene og (iii) økte priser på matvarer og energi:

- Boligprisene i USA begynte å falle mot slutten av 2006, og prisene går nå også ned i en rekke andre land. Dette fører til lavere aktivitet i byggenæringen, og kan også føre til lavere privat forbruk.

- Høy vekst og økt etterspørsel globalt, særlig fra land som Kina og India mv., har gitt økte priser på matvarer og energi. Frykt for at inflasjonen kan bite seg fast på et høyere nivå har begrenset pengepolitikkens rom for å stimulere produksjon og sysselsetting i flere land. De siste månedene har imidlertid både oljeprisen og råvareprisene falt noe tilbake.

- Uroen i finansmarkedene det siste året har ført til økt usikkerhet i økonomien og gjort banker mer tilbakeholdne med å yte kreditt til bedrifter og foretak. Etter at den amerikanske investeringsbanken Lehman Brothers gikk konkurs 15. september, forverret situasjonen i finansmarkedene seg raskt, og myndighetene i både USA og Europa har måttet trå til med redningspakker for å dempe utslagene.

Problemene i finansmarkedene og svakere vekstutsikter gjorde at den amerikanske sentralbanken satte styringsrenten ned seks ganger det siste året, fra $4 \frac{1}{4}$ til 2 pst. Sentralbanken i Storbritannia reduserte i samme periode styringsrenten med $3 / 4$ prosentpoeng til 5 pst. Den europeiske sentralbanken hevet styringsrenten fra 4 til $4 \frac{1}{4}$ pst. på rentemøtet i juli, etter å ha hold renten uendret siden juni 2007. Renteøkningen ble begrunnet med faren for at den høye konsumprisveksten skal slå ut i generelt økt lønns- og prispress. Den japanske sentralbanken har holdt styringsrenten fast på $1 / 2$ pst. siden februar 2007. I en samordnet aksjon 8. oktober, kuttet sentralbankene i blant annet USA, euroområdet, Storbritannia og Sverige styringsrenten med $1 / 2$ prosentpoeng, slik at renten nå er 13/4 pst. i USA, 33/4 pst. i euroområdet, og 41/2 pst. i Storbritannia. 


\subsection{Nærmere om uroen i finansmarkedene}

Uroen i finansmarkedene startet $\mathrm{i}$ august $\mathrm{i}$ fjor og hadde sitt utspring $\mathrm{i}$ markedet for såkalte subprimelån i det amerikanske boliglånsmarkedet. Dette er lån til husholdninger som ikke oppfyller ordinære lånekriterier. Da boligprisene først flatet ut og deretter tok til å falle og rentekostnadene økte, gikk omfanget av misligholdte boliglån og tap for långivere i dette markedet markert opp. De relativt begrensede beløpene knyttet til dette lånemarkedet er imidlertid ikke i seg selv nok til å skape problemer av et slikt omfang som nå utspiller seg.

Problemene finanssektoren står overfor i dag, har mange av de samme kjennetegnene en har sett i tidligere perioder med finansmarkedsproblemer. Den lange perioden med lave renter har bidratt til utbredt optimisme og gjort det relativt rimelig å lånefinansiere investeringer i finansmarkedene. Sammen med lav prising av risiko har dette ført til økt etterspørsel etter verdipapirer, en markert oppgang i kredittvekst og aktivapriser og bidratt til at finansinstitusjonenes balanser er økt betydelig. Utviklingen har også avdekket svakheter ved virksomhets- og risikostyringen i finansinstitusjonene, og myndighetene i USA og europeiske land har erkjent svakheter i finansmarkedsreguleringer.

Verdipapirisering $^{1}$ og salg av boliglån gjennom ulike strukturerte produkter har betydd at risiko er blitt spredt fra banker til andre finansinstitusjoner og investorer. En slik spredning av risiko ble i utgangspunktet vurdert å gjøre både bankene og det finansielle systemet som helhet mer robust mot finansielle kriser. I ettertid er det imidlertid klart at denne utviklingen har bidratt betydelig til de problemene man nå observerer.

Salg og videresalg til investorer både i og utenfor USA av til dels kompliserte, strukturerte spareprodukter gjorde det vanskelig å identifisere hvilke verdipapirer som var tapsutsatte, hvilke institusjoner som var eksponert mot slike verdipapirer, og hvilken verdsettelse en burde legge til grunn. Usikkerheten som bredte seg førte til at slike verdipapirer ble vanskelige å omsette. I tillegg ble banker tilbakeholdne med å låne likviditet til andre banker og finansinstitusjoner. Dette ledet til en svært anstrengt likviditetssituasjon i pengemarkedene. Den premien banker må betale for likviditetsrisikoen knyttet til lån i pengemarkedet, har økt markert, og flere banker har i perioder fått store problemer med å refinansiere utestående gjeld. For investeringsbankene, som i stor grad har finansiert sin virksomhet med kortsiktige innlån i pengemarkedet, har situasjonen blitt særlig vanskelig. Prisen for å sikre seg mot kredittrisiko, gitt ved

\footnotetext{
${ }^{1}$ Et utviklingstrekk som skiller seg fra tidligere er den framtredende plassen verdipapirisering og utviklingen av nye spareprodukter har fått i det amerikanske finansmarkedet. Verdipapirisering innebærer at lån blir pakket sammen og videresolgt til boliglånsinstitusjoner eller andre investorer. Kjøpet finansieres ved utstedelse av verdipapirer med sikkerhet i de underliggende papirene. Verdipapirene er gjerne oppdelt i ulike transjer rangert etter sikkerheten på de underliggende papirene. Disse verdipapirene har igjen blitt «pakket om» og dannet grunnlag for nye verdipapirer og såkalte strukturerte produkter.
} 
prisen på såkalte "credit default swapper” (CDS), økte også sterkt for både banker og andre selskaper.

Finansuroen eskalerte i annen halvdel av september da den store amerikanske investeringsbanken Lehman Brothers gikk konkurs 15. september. Konkursen innebar at banker over hele verden ble enda mer tilbakeholdne med å låne hverandre penger, og pengemarkedsrentene gikk markert opp. Usikkerheten ble forsterket av uenigheten rundt den foreslåtte krisepakken i USA. Da en revidert pakke ble vedtatt, var det ikke tilstrekkelig til å normalisere markedene. I mange land måtte myndighetene gå inn med tiltak for å redde tapsutsatte finansinstitusjoner.

For å stabilisere markedene har sentralbanker i en rekke land det siste året tilført ekstra likviditet, og myndigheter har gått inn og reddet store finansinstitusjoner for å sikre videre drift. De store sentralbankene har flere ganger iverksatt samordnede tiltak for å tilføre likviditet til banksystemet. Koordineringen ble ytterligere styrket da sentralbankene i USA, euroområdet, Storbritannia, Canada og Sverige satte ned styringsrentene med $1 / 2$ prosentpoeng den 8 . oktober. Ved samme anledning reduserte sentralbankene i Kina og Sveits sine renter med 1/4 prosentpoeng.

Den 10. oktober uttrykte finansministrene og sentralbanksjefene i G-7 landene enighet om at den nåværende situasjonen krever raske og usedvanlige tiltak. Etter dette ble det på EU-toppmøtet 15. oktober enighet om samordnede tiltak på nasjonalt plan for å sikre at det finansielle systemet fungerer.

\subsection{Den økonomiske utviklingen i Norden}

Den økonomiske utviklingen har vært sterk over flere år også i de nordiske landene. Det siste året er imidlertid også de nordiske landene blitt rammet av uroen i finansmarkedene. Selv om høy vekst gjennom flere år har bidratt til å gjøre landene robuste til å møte de utfordringene uroen skaper, har risikoen for lavere økonomisk vekst framover økt. Finansuroen har videre rammet de ulike nordiske landene i ulik grad. Myndighetene i Danmark, Island, Norge og Sverige har selv iverksatt ektraordinære tiltak for å møte uroen, og Finland tar del i tiltakene i EU. Island er rammet hardere enn de andre landene, jf. omtale av Island i kapittel 4.

Den økonomiske veksten i Norden begynte å avta i 2007, og ligger an til å bremse ytterligere opp i 2008 og 2009. Mens samlet BNP-vekst i 2007 var på 3,6 pst., indikerer prognosene lagt til grunn i de enkelte landene en vekst på 2,0 pst. i 2008 og 1,3 pst. i 2009. Den avtakende veksten skyldes lavere eksportvekst og lavere vekst i innenlands etterspørsel. Lavere eksportvekst skyldes både svakere etterspørselsimpulser fra eksportmarkedene og svekkelse av den kostnadsmessige konkurranseevnen i enkelte land . Boligmarkedene svekker seg i alle nordiske land, og boliginvesteringene ventes å falle. Usikkerheten i boligmarkedene og fallende 
aksjepriser bidrar til å dempe veksten i husholdningenes konsumetterspørsel.

I Danmark ble konjunkturtoppen nådd i 2006, og veksten har siden avtatt, blandt annet som følge av svak produktivitetsvekst og mangel på arbeidskraft, som begrenser vekstmulighetene. I Økonomisk Redegørelse, august 2008 ventes BNP i år å vokse med 1,1 pst., og til neste år ventes en vekst på 0,5 pst. Den avdempede veksten avspeiler bl.a. et ventet fall i boliginvesteringene fra et høyt nivå som følge av synkende boligpriser, samt avdempet eksport som må ses i sammenheng med utviklingen i konkurranseevnen og svakere vekst internasjonalt.

I Finland vokste BNP med 4,5 pst. i 2007, og den sterke veksten fortsatte inn i 2008. Veksten ser imidlertid nå ut til å ha avtatt, og veksten ventes å bli på 2,8 pst. i år og 1,8 pst. til neste år. Eksportveksten ventes å avta, noe som må sees i sammenheng både med svakere utvikling internasjonalt og med svekket konkurranseevne i industrien som følge av økende lønnskostnader og en sterk euro. Boliginvesteringene vokser også langsommere, som følge av mer usikkerhet i boligmarkedet. Privat forbruk har vokst raskt i flere år, men veksten ventes nå å avta.

På Island har den økonomiske veksten vært svært høy de siste årene, men den siste tiden har veksten avtatt markert. I Finansdepartementets anslag fra september ble veksten i BNP for 2008 anslått til 1,7 pst. Den internasjonale finanskrisen har rammet Island særlig hardt, og det er grunn til å tro at veksten i både 2008 og 2009 vil bli klart lavere enn det Finansdepartementet anslo i september. Usikkerheten rundt omfanget av tilbakeslaget er imidlertid så stor at det er vanskelig å tallfeste hvor mye lavere veksten kan bli.

Norges BNP for Fastlands-Norge økte med 5 pst. årlig i fireårsperioden 2004-2007, og veksten var på hele 6,2 pst. i 2007. Både produksjon og etterspørsel har økt klart saktere etter årsskiftet enn i de siste årene, og i Nasjonalbudsjettet 2009 anslås veksten i BNP for Fastlands-Norge til vel 3 pst. i år og knapt 2 pst. neste år. Avdempingen i den økonomiske veksten må ses i sammenheng med lavere vekst i husholdningenes forbruk og svakere etterspørselsimpulser fra eksportmarkedene.

Også Sverige har hatt flere år med rask økonomisk vekst, som nå ser ut til å avta raskt. Etter en BNP-vekst på 2,7 pst. i fjor, ventes en vekst på 1,5 pst. i år og 1,3 pst. til neste år. Børsfall, fortsatt høy inflasjon og usikkerhet på boligmarkedet bidrar til svakere konsumetterspørsel fra husholdningene. Dette motvirkes i noen grad av den finanspolitiske stimulansen i 2009. Den svakere utviklingen internasjonalt og svakere konkurranseevne som følge av lagsommere produktivitetsvekst i 2007 og starten på 2008 bidrar til å dempe eksportveksten. Veksten i bedriftsinvesteringene ventes også å avta, dels som følge av langsommere etterspørselsvekst, og dels fordi uroen på finansmarkedene fører til vanskeligere tilgang på kreditt. 


\subsection{Arbeidsmarkedet}

Sysselsettingen i de nordiske landene har økt gjennom de siste årenes oppgangskonjunktur, og arbeidsledigheten har falt. Når landene nå er i ferd med å gå inn i en svakere vekstfase ventes arbeidsledigheten igjen å øke noe. For regionen sett under ett, har arbeidsledigheten falt fra 6,8 pst. i 2004 til 4,8 pst. i 2007. Bunnpunktet i denne konjunktursyklusen blir inneværende år. Da ventes arbeidsledigheten i Norden å falle til 4,4 pst., før den øker svakt til 4,6 pst. til neste år.

I Danmark har arbeidsledigheden falt i nesten 5 år i strekk og var i august i år drøyt 11/2 pst. av arbeidsstyrken, hvilket er historisk lavt. Sysselsettingen er samtidig steget til et rekordhøyt nivå. I takt med en "normalisering” av konjunktursituasjonen i Danmark ventes ledigheden i Økonomisk Redegørelse, august 2008 å stige til omkring 21/2 pst. ved utgangen av 2009. Dette er om lag 11/4 prosentpoeng under anslaget for den strukturelle ledigheten ved utgangen av 2009.

I Finland har sysselsettingen økt med 125000 personer fra 2005 til 2007, og ventes øke med ytterligere 40000 personer i 2008. Mange næringer har mangel på arbeidskraft, på tross av at arbeidstilbudet har økt, både grunnet økt arbeidsstyrkedeltagelse blant eldre og blant unge voksne, og grunnet økt arbeidsinnvandring. Etter flere år med sterk vekst, antas sysselsettingen nå å bli uendret fra 2008 til 2009. Likevel antas Finland som eneste land i Norden å oppleve fortsatt fallende arbeidsledighet i 2009, som følge av synkende arbeidsstyrkedeltagelse, men risikoen for en svakere utvikling har økt de siste ukene.

Arbeidsledigheten på Island har vært svært lav de siste årene. Den registrerte ledigheten utgjorde 1 pst. av arbeidsstyrken i 2007. Arbeidsledigheten har økt noe i år og utgjorde i september 1,3 pst. av arbeidsstyrken. I den siste tiden har det vært betydelige nedbemanninger i finanssektoren og ledighetsraten forventes å stige fra 2007 til 2008. Arbeidsledigheten ventes å stige ytterligere neste år.

I Norge har sysselsettingsveksten vært svært høy over flere år. Fra 2006 til 2007 økte sysselsettingen med hele 98000 personer, eller 4 pst. Veksten i sysselsettingen har dempet seg klart av den siste tiden og arbeidsledigheten har flatet ut på rundt $21 / 2$ pst. av arbeidsstyrken. I Nasjonalbudsjettet 2009 antas det at lavere vekst i fastlandsøkonomien vil bidra til en forsiktig økning i arbeidsledigheten, fra $2 \frac{1}{2} 2$ pst. av arbeidsstyrken i 2008 til 23/4 pst. i 2009.

Etter lengre tids positiv utvikling i arbeidsmarkedet, har sysselsettingsveksten i Sverige nå begynt å avta. I 2008 ventes sysselsettingen å vokse med 1,2 pst., for deretter å ligge uforandret i 2009. Arbeidsstyrken ventes derimot å fortsatt øke, både på grunn av demografiske endringer, og på grunn av gjennomførte reformer som øker insentivene for å stå i arbeid. Derfor antas arbeidsledigheten å øke noe, fra 6,0 pst. i år, til 6,4 pst. til neste år. 
Tabell 1.1 Nøkkeltall, Norden ${ }^{1}$. Prosentvis årlig endring

\begin{tabular}{|c|c|c|c|c|c|c|}
\hline & 2004 & 2005 & 2006 & 2007 & 2008 & 2009 \\
\hline \multicolumn{7}{|l|}{ BNP-vekst, \% } \\
\hline Danmark & 2,3 & 2,5 & 3,9 & 1,7 & 1,1 & 0,5 \\
\hline Finland & 3,7 & 2,8 & 4,9 & 4,5 & 2,8 & 1,8 \\
\hline Island & 7,7 & 7,4 & 4,4 & 4,9 & & \\
\hline Fastlands-Norge & 4,4 & 4,6 & 4,8 & 6,2 & 3,1 & 1,9 \\
\hline Sverige & 4,1 & 3,3 & 4,1 & 2,7 & 1,5 & 1,3 \\
\hline Norden & 3,6 & 3,3 & 4,4 & 3,5 & 2,0 & 1,3 \\
\hline \multicolumn{7}{|l|}{ Inflasjon, \% } \\
\hline Danmark & 1,2 & 1,8 & 1,9 & 1,7 & 3,5 & 2,7 \\
\hline Finland & 0,2 & 0,9 & 1,6 & 2,5 & 4,1 & 2,8 \\
\hline Island & 3,2 & 4,0 & 6,8 & 5,0 & & \\
\hline Norge & 0,5 & 1,5 & 2,3 & 0,8 & $33 / 4$ & 3 \\
\hline Sverige & 0,4 & 0,5 & 1,4 & 2,2 & 3,8 & 2,4 \\
\hline Norden & 0,6 & 1,1 & 1,8 & 1,8 & 3,8 & 2,7 \\
\hline \multicolumn{7}{|l|}{ Arbeidsledighet, \% } \\
\hline Danmark & 5,6 & 4,9 & 3,8 & 2,7 & 1,7 & 2,2 \\
\hline Finland & 8,8 & 8,4 & 7,7 & 6,9 & 6,2 & 5,9 \\
\hline Island & 3,1 & 2,6 & 2,9 & 2,3 & & \\
\hline Norge & 4,5 & 4,6 & 3,4 & 2,5 & $21 / 2$ & $23 / 4$ \\
\hline Sverige & 7,7 & 7,7 & 7,1 & 6,2 & 6,0 & 6,4 \\
\hline Norden & 6,8 & 6,6 & 5,7 & 4,8 & 4,4 & 4,6 \\
\hline \multicolumn{7}{|c|}{ Offentlig sparing, $\%$ av BNP } \\
\hline Danmark & 1,9 & 5,0 & 4,9 & 4,8 & 3,6 & 3,0 \\
\hline Finland & 2,2 & 2,7 & 4,0 & 5,3 & 5,0 & 3,6 \\
\hline \multicolumn{7}{|l|}{ Island } \\
\hline Norge & 11,1 & 15,1 & 18,5 & 17,5 & 20,1 & 16,4 \\
\hline Sverige & 0,6 & 2,0 & 2,2 & 3,5 & 2,8 & 1,1 \\
\hline Norden & 3,5 & 5,7 & 6,7 & 7,2 & 7,1 & 5,3 \\
\hline \multicolumn{7}{|c|}{ Driftsbalansen, \% av BNP } \\
\hline Danmark & 3,0 & 4,4 & 2,9 & 1,1 & 1,3 & 2,0 \\
\hline Finland & 2,7 & 3,5 & 4,1 & 4,8 & 4,8 & 3,8 \\
\hline \multicolumn{7}{|l|}{ Island } \\
\hline Norge & 12,7 & 16,3 & 17,3 & 15,4 & 20,5 & 16,6 \\
\hline Sverige & 6,7 & 6,8 & 8,5 & 8,5 & 8,3 & 8,4 \\
\hline Norden & 6,3 & 7,6 & 8,2 & 7,5 & 8,5 & 7,7 \\
\hline
\end{tabular}

1: Samlet anslag for Norden er beregnet utenom Island. Kilder: Nasjonale kilder 


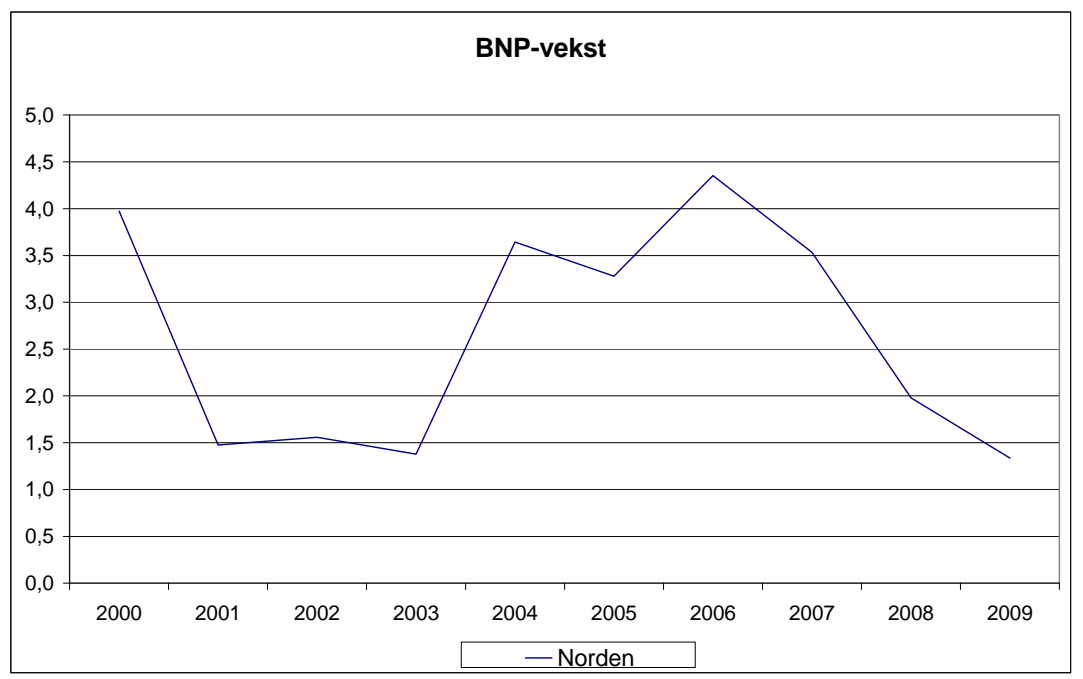

Figur1.1 BNP-vekst. Prosentvis årlig endring, veid gjennomsnitt utenom Island'

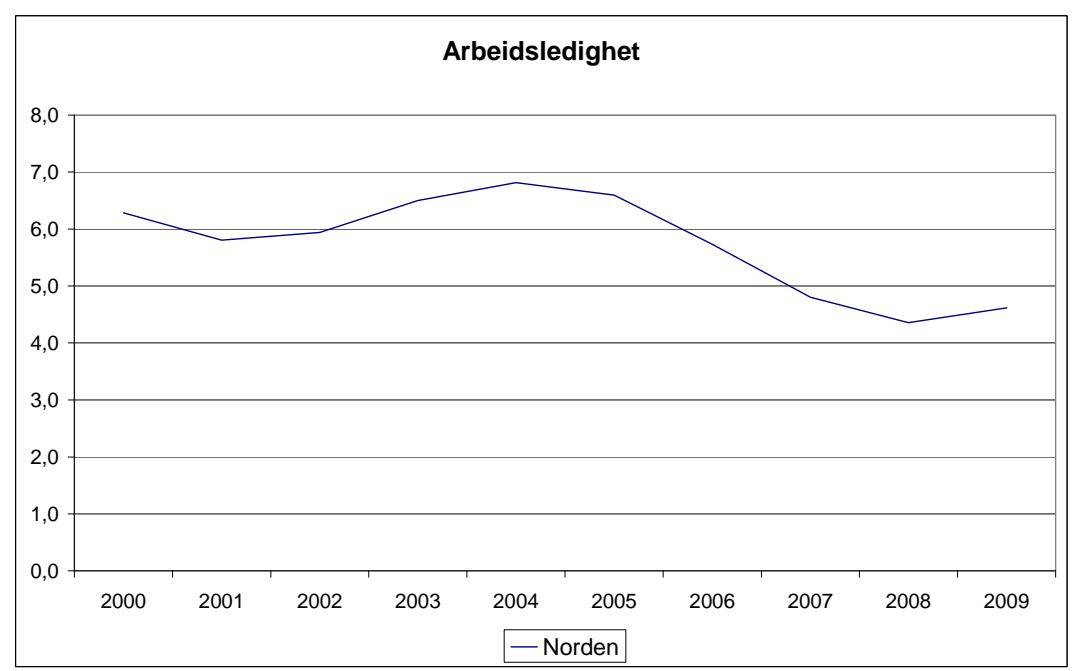

Figur1.2 Arbeidsledighet. Prosent av arbeidsstyrken, veid gjennomsnitt utenom Island 



\section{Danmark}

\subsection{Den økonomiske politik}

Det er et mål for den økonomiske politik at sikre holdbar økonomisk vækst, høj beskæftigelse og lav og stabil inflation. Med henblik på at opnå disse mål er der i tilrettelæggelsen af den økonomiske politik et særligt fokus på at sikre tilstrækkelig arbejdskraft til både den private og offentlige sektor. Herunder ikke mindst med henblik på at håndtere udfordringerne fra den demografiske udvikling, hvor der bliver flere ældre og færre i de mest erhvervsaktive aldersgrupper. En anden udfordring er at ruste det danske samfund til globaliseringen og sikre, at alle grupper i samfundet deltager og får del i den fremgang, der opnås som følge af globaliseringen.

Finanspolitikken tilrettelægges efter den flerårige økonomiske plan Mod nye mål - Danmark 2015. 2015-planen sigter bl.a. på at sikre finanspolitisk holdbarhed, således at velfærdssamfundet også kan finansieres på langt sigt, uden at der fremkommer et behov for større fremtidige finanspolitiske stramninger. Det skal ske med en kombination af strukturreformer og nedbringelse af den offentlige gæld i disse år, hvor mulighederne herfor er særligt gunstige. Det er således målsætningen, at der frem mod 2010 fastholdes strukturelle offentlige overskud mellem 3/4 og 13/4 pct. af BNP, og at der fra 2011 til 2015 skal være mindst balance. Sigtet i planen er dermed også, at de automatiske stabilisatorer skal kunne bidrage fuldt ud til at stabilisere den økonomiske udvikling.

I 2015-planen fremgår desuden, at finanspolitikken skal understøtte en stabil økonomisk udvikling, og at det blandt andet fordrer "tilbageholdenhed i finanspolitikken og tilstrækkelige offentlige overskud, når konjunkturerne er gode og ledigheden lav”. Ved at føre tilbageholdende finanspolitik i gode tider, hvor ledigheden er lav, sikres samtidig det nødvendige råderum til at handle i en lavkonjunktur, hvor ledigheden er over det strukturelle niveau (og lønudviklingen dermed er afdæmpet).

Det centrale udgangspunkt for stabiliseringspolitikken er således kapacitetsudnyttelsen i økonomien - dvs. niveauet for aktivitet, ledighed, betalingsbalance osv. i forhold til et "normalt" eller strukturelt niveau og ikke niveauet for væksten. I den aktuelle situation er kapacitetsudnyttelsen (outputgabet) som udgangspunkt klart positivt, og det skønnes at være højere end under de to foregående opsving. Samtidig er løn- og prisstigningerne forholdsvis høje. Heroverfor står, at der aktuelt er stor usikkerhed om det videre forløb, bl.a. med risiko for meget svag vækst i udlandet og i Danmark som følge af finansiel uro, vigende boligmarkeder i mange lande og udsigt til en ret kraftig tilpasning især i USA. 
Det centrale i den aktuelle situation er den betydelige usikkerhed, der knytter sig til det videre forløb. Det er en usikkerhed, der fordrer, at handlemulighederne i finanspolitikken - dvs. mulighederne for at lempe den økonomiske politik med henblik på at stabilisere konjunkturerne - bevares og i givet fald først anvendes, når inflationspresset (og presset på rentespændet) er ude af økonomien.

Samtidig er det et vigtigt hensyn, at den økonomiske politik indrettes efter at opnå en indsnævring af rentespændet, som pt. er udvidet til 1,75 pct., således at også Danmark får gavn af rentenedsættelser fra ECB’s side. Det vil bidrage til at holde hånden under boligmarkedet, samtidig med at kapacitetsforholdene normaliseres, og presset på lønudviklingen tager af.

Perioder med finansiel uro stiller særlige krav til den økonomiskpolitiske disciplin i små økonomier, der som Danmark fører fastkurspolitik, men ikke er med i euroen. Tilbageholdenhed i finanspolitikken bidrager til, at inflationen i Danmark bringes ned til samme niveau som i euroområdet. Det understøtter fastkurspolitikken og kan sikre grundlaget for, at rentespændet overfor euroområdet kan sænkes.

\subsection{Udviklingen i dansk økonomi}

Væksten i produktionen har været afdæmpet gennem det seneste år. Det afspejler blandt andet svag produktivitetsvækst og mangel på arbejdskraft, som begrænser vækstmulighederne. Ledigheden er fortsat med at falde til et ekstraordinært lavt niveau på godt $1 \frac{1}{2} \mathrm{pct}$. af arbejdsstyrken i august. Det har medført en kraftig opgang i lønstigningerne på det private arbejdsmarked til knap 5 pct. i 2. kvartal i år. Det er væsentligt over niveauet hos Danmarks samhandelspartnere og indebærer en fortsat svækkelse af lønkonkurrenceevnen. Samtidig er inflationen steget stejlt og udgjorde i september 4,2 pct. (4,5 pct. i den EU-harmoniserede opgørelse). Det er det højeste niveau i næsten 20 år, og inflationen er nu op mod 1 pct.-enhed større end i euroområdet. Opgangen i inflationstakten afspejler især en international opgang i priserne på fødevarer og energi men også større indenlandsk inflationspres, bl.a. som følge af ret store stigninger i enhedslønomkostningerne.

Siden årsskiftet er væksten i den private indenlandske efterspørgsel bremset væsentligt op bl.a. som følge af stigningen i inflationen og den finansielle uro, som har påvirket forventningerne negativt og derved formentlig givet anledning til større forsigtighed i forbrugs- og investeringsbeslutninger. På boligmarkedet er der svagt vigende priser på landsplan, som afspejler tydelige prisfald i de områder (herunder især Københavnsområdet), hvor priserne steg mest frem mod 2006. Boligejernes økonomi er imidlertid generelt robust, og de kraftige stigninger i boligværdierne de senere år er ikke belånt i væsentligt omfang. Aktivitetsniveauet er samti- 
dig fortsat på et højt niveau, og lavere vækst i den samlede efterspørgsel er en betingelse for, at presset på lønninger, priser og konkurrenceevne dæmpes.

Fremadrettet ventes en fortsat "normalisering" af konjunktursituationen med afdæmpet vækst de kommende år. I Økonomisk Redegørelse, august 2008 ventes således en vækst på godt 1 pct. i år og 1/2 pct. næste år. Samtidig forventedes, at ledigheden stiger til ca. 21/2 pct. af arbejdsstyrken ved udgangen af 2009. Det er ca. 11/4 pct.-enhed under skønnet for den strukturelle ledighed ved udgangen af 2009. Den afdæmpede vækst afspejler bl.a. et ventet fald i boliginvesteringerne fra et højt niveau herunder som følge af vigende boligpriser, samt afdæmpet eksport i lyset af konkurrenceevneudviklingen og svagere internationale vækstudsigter. Den mindre vækst i efterspørgslen reducerer importvæksten, og overskuddet på betalingsbalancen skønnes at blive 11/4 pct. af BNP i 2008 og 2 pct. af BNP i 2009.

Overskuddet på de offentlige finanser skønnes i Økonomisk Redegørelse, august 2008 at udgøre 641/2 mia. kr. i 2008 (3,6 pct. af BNP) og ca. 553/4 mia. kr. i 2009 (3,0 pct. af BNP). Det offentlige finansielle nettotilgodehavende øges på den baggrund til godt 91/4 pct. af BNP i 2009 mod godt 3 pct. af BNP i 2007. Korrigeret for konjunkturernes påvirkning og andre midlertidige forhold udgør det beregnede strukturelle overskud 1,6 pct. af BNP, mens det for 2009 er beregnet til 1,2 pct. af BNP. Det er i begge år inden for det opstillede målinterval, der tilsiger strukturelle overskud mellem 3/4 og 13/4 pct. af BNP frem mod 2010.

Aktivitetsvirkningen fra finanspolitikken skønnes til 0,1 pct. i 2008 og til 0,3 pct. i 2009 på baggrund af regeringens forslag til finanslov for 2009. Aktivitetsvirkningen i 2009 skal ses i sammenhæng med, at der i finanslovforslaget indgår forskellige initiativer, som styrker arbejdsudbuddet, herunder forøgelsen af mellemskattegrænsen og initiativerne i Jobplanen.

Gennem den seneste måneds tid er den finansielle krise taget markant til i styrke, og der er gennemført meget gennemgribende indgreb i den finansielle sektor i mange lande, navnlig med sigte på at få interbankmarkederne til at fungere igen. Den skærpede finansielle uro har medført større usikkerhed om det videre forløb og har samtidig bidraget til, at centrale antagelser bag augustvurderingen formentlig må revideres i forbindelse med den kommende vurdering i Økonomisk Redegørelse, december 2008.

Modelberegninger, som på overordnet niveau forsøger at inddrage betydningen af de nye informationer omkring oliepriser, valutakurser, renter, aktiekurser og lavere vækst i udlandet, peger samlet i retning af en vækst på 3/4-1 pct. i år og 0-1/2 pct. næste år. Det er samtidig sandsynligt, at det offentlige overskud kan komme ned omkring 3/4 pct. af BNP i 2009 (under 15 mia. kr.) mod et ventet overskud på 3 pct. af BNP (ca. 56 mia. kr.) i augustvurderingen. Det afspejler helt overvejende mindre provenu 
fra de volatile indtægter fra Nordsøen og fra pensionsafkastskatten som følge af de store fald i oliepriser og aktiekurser gennem de seneste måneder. Den strukturelle saldo vurderes at være omtrent på linje med augustskønnet og dermed inden for målintervallet i 2015-planen.

Der er derudover meget betydelig usikkerhed om virkningerne af finanskrisen i øvrigt. Det gælder mulige ændringer i bankernes kreditgivning og afledte effekter på danskernes forbrug og virksomhedernes investeringer. Og det gælder virkningen af de politiske indgreb, der er foretaget i mange lande for at afhjælpe problemerne i den finansielle sektor, samt de rentenedsættelser, der er foretaget fra en række centralbanker. Den danske realøkonomi står under alle omstændigheder i en god position til at rumme de udfordringer, som den finansielle uro og vigende vækst i udlandet fører med sig.

\subsection{Udsigterne på mellemlangt sigt}

Uanset hvordan det går med verdensøkonomien de næste par år, vil det fortsat være en central udfordring at øge arbejdsudbuddet i lyset af det demografiske pres på beskæftigelse, arbejdstid og de offentlige udgifter. Det vil bidrage til at styrke vækstmulighederne og den langsigtede sammenhængskraft i finanspolitikken.

I lyset af den kraftige nedgang i ledigheden blev der med Jobplanen fra februar 2008 sigtet på at øge arbejdsudbuddet navnlig på kortere sigt. Jobplanen er en 10-punkt plan med konkrete initiativer til at skaffe mere arbejdskraft i Danmark - dels ved at give overførselsmodtagere bedre mulighed for at komme i arbejde og dels ved at tiltrække kvalificeret arbejdskraft fra udlandet.

I 2015-planen er det et krav, at nye initiativer skal øge den strukturelle beskæftigelse med 20.000 personer og sikre, at den gennemsnitlige arbejdstid ikke falder. Det svarer til 50-60.000 fuldtidsbeskæftigede Der er nedsat en Arbejdsmarkedskommission og en Skattekommission bestående af uafhængige eksperter, som skal komme med forslag til sådanne initiativer. Da ledigheden er faldet mere end ventet og aktuelt er meget lav, har Arbejdsmarkedskommissionen på anmodning fra regeringen fremskyndet sit arbejde og i september fremlagt forslag til yderligere reformer, der kan øge arbejdsudbud og beskæftigelse inden for en kortere tidshorisont. En række af forslagene indgår i forhandlingerne om Finansloven for 2009. Kommission skal endeligt afrapportere i midten af 2009.

På baggrund af forslag fra Skattekommissionen er det regeringens mål at gennemføre en skattereform, der sænker skatten på arbejdsindkomst yderligere og dermed øger vækstpotentialet i økonomien. Skattepolitikkens omdrejningspunkt er fortsat skattestoppet, der indebærer, at en skat eller afgift ikke må stige, uanset om den er fastsat i procent eller nominelle kronebeløb. Dog indekseres energiafgifterne som led i energi- og kli- 
mastrategien, og merprovenuet herfra medgår merprovenuet fra energiafgifterne til nedsættelse af skatten på arbejde. I forbindelse med skattereformen åbnes mulighed for større omlægninger, så længe provenuet fra forhøjelse af én skat går til at sænke en anden skat.

Under forudsætning af gennemførelsen af de krævede arbejdskraftforøgende initiativer og en produktivitetsvækst, som svarer til gennemsnittet siden 1990, påregnes i 2015-planen en vækst, som er ca. 11/4 pct. på årsbasis frem mod 2015. Fremskrivningen er ikke en egentlig prognose, men skal ses som et grundlag for tilrettelæggelsen af finanspolitikken. Forløbet i 2015-planen afspejler dels den normalisering af konjunktursituationen, som nu ser ud til at være i gang, men også negative bidrag til arbejdsstyrken fra demografi og underliggende fald i arbejdstiden, som i planen antages modvirket af strukturreformer.

De nuværende store overskud på den offentlige saldo forventes at aftage frem mod 2015. I 2015 ventes et overskud på de offentlige finanser på knap $1 / 2$ pct. af BNP. De aftagende overskud skal ses i lyset af navnlig en normalisering af konjunkturerne, faldende Nordsø-indtægter og stigende udgifter til folkepension mv.

De offentlige overskud betyder en fortsat nedbringelse af den offentlige gæld. Forløbet frem mod 2015 indebærer, at ØMU-gælden nedbringes fra 20 pct. af BNP i 2008 til omkring 15 pct. af BNP i 2015, og at nettogælden vendes til et nettotilgodehavende.

Tabell 2.1 Nyckeltal förDanmarks ekonomi (Økonomisk Redegørelse, august 2008). Procentuell förändring. ${ }^{1)}$

\begin{tabular}{|c|c|c|c|c|}
\hline & Mdr. kronor 2007 & 2007 & 2008 & 2009 \\
\hline \multicolumn{5}{|l|}{ Fasta priser } \\
\hline Hushållens konsumtionsutgifter & 839,8 & 2,3 & 1,6 & 1,1 \\
\hline Offentliga konsumtionsutgifter & 438,8 & 1,6 & 1,6 & 1,1 \\
\hline Fasta bruttoinvesteringar & 388,2 & 5,9 & 0,0 & $-3,0$ \\
\hline Näringsliv & 239,7 & 8,8 & 1,2 & $-2,7$ \\
\hline Bostäder & 118,6 & 4,5 & $-3,0$ & $-5,0$ \\
\hline Myndigheter & 29,9 & $-9,0$ & 2,0 & 0,5 \\
\hline Lagerinvesteringar $^{2)}$ & 8,2 & $-0,3$ & 0,1 & 0,0 \\
\hline Total inhemsk efterfrågan & $1.675,0$ & 2,6 & 1,3 & 0,2 \\
\hline Export & 885,0 & 1,9 & 3,0 & 1,9 \\
\hline Import & 863,6 & 3,8 & 3,5 & 1,3 \\
\hline Bruttonationalprodukt & $1.696,3$ & 1,7 & 1,1 & 0,5 \\
\hline Sysselsättning, 1000 personer & - & 2.814 & 2.838 & 2.817 \\
\hline Arbetslöshet (\% av arbetskraften, DK-def.) & - & 2,7 & 1,7 & 2,2 \\
\hline Konsumtionsprisindex & - & 1,7 & 3,5 & 2,7 \\
\hline Lön $^{3)}$ & - & 4,1 & 4,7 & 4,6 \\
\hline Effektiv valutakurs ${ }^{4)}$ & - & 1,1 & 3,0 & 0,4 \\
\hline Bytesförhållande, varor & - & $-1,1$ & 1,2 & 0,5 \\
\hline Bytesbalans (\% av BNP) & - & 1,1 & 1,3 & 2,0 \\
\hline 3-månaders penningmarknadsränta (nivå) & - & 4,4 & 5,1 & 4,8 \\
\hline
\end{tabular}

1) Beräknat i foregående års priser. 2) Förändring i procent av föregående års BNP. 3) Timlön för privat anställda, DA-løn. 4) Negativt tal innebär depreciering. Källor: Økonomisk Redegørelse, august 2008. 



\section{Finland}

\subsection{Den ekonomiska politiken}

Den ekonomiska politiken i Finland har under de senaste åren stött den stabila ekonomiska tillväxten och sysselsättningen genom skatteåtgärder och anslagsökningar som förbättrar förutsättningarna för ekonomisk tillväxt. Nästa år kan finanspolitiken som helhet bedömas främja den totala efterfrågan och tillväxten. I bakgrunden finns bl.a. de skattelösningar som genomförts.

Statens budgetförslag för 2009 har ett överskott på 153 miljoner euro och statens fondekonomi på 1,4 miljarder euro 2009. Enligt nationalräkenskaperna kommer nästa års överskott i statsfinanserna att vara 0,7 \% i förhållande till bruttonationalprodukten. Statsskulden beräknas vara 54 miljarder euro i slutet av 2009 och skuldens BNP-förhållande sjunker till 27 \%. Nästa år lättas beskattningen av arbete upp med 870 miljoner euro. Dessutom justeras beskattningen för att motsvara ökningen av inkomstnivån vilket är betydligt mera än justeringen för inflationstakten. Beskattningen av pensionstagarna lättas upp i motsvarande grad, så att beskattningen ska ligga på högst samma nivå som beskattningen av arbetsinkomster. Det maximala hushållsavdraget för vissa renovering och hembiträde arbete höjs till 3000 euro. Mervärdesskattesatsen för livsmedel sänks till $12 \%$ från och med 1.10.2009 och att virkesförsäljningsinkomster partiellt befrias från skatt för en viss tid för att trygga tillgången på virke för skogsindustrin. Minimibeloppen av moderskaps-, faderskapsoch föräldrapenning samt sjukdagpenning och rehabiliteringspenning stiger till samma nivå som arbetsmarknadsstödet i början av nästa år.

Den offentliga ekonomins finansiella situation förblir god i år, 5 \% /BNP, trots att statens finansiella sparande sjunker med knappt $1 / 2$ procentenhet. Inkomstutveckling har varit fortsatt stark och totala utgifter ökar i år med 51/2\%, då både konsumtionsutgifterna och investeringarna ökar kännbart från i fjol. Socialskyddsfondernas överskott ligger fortfarande kring $3 \%$ i förhållande till totalproduktionen. Den offentliga ekonomins skuld sjunker i år till 32 \% av bruttonationalprodukten. År 2009 förutspås den offentliga ekonomins finansiella situation försämras klart, med 11/2 procentenhet i relation till total produktionen. Orsakerna till detta är det försämrade konjunkturläget, skattelättnaderna samt förmögenhetsinkomsterna, som börjar minska jämfört med rekordnivån. Trots försämringen förblir den finansiella situationen god, $3 \frac{1}{2} \%$ /BNP.

De finländska bankernas situation är enligt inansinspektionen god för tillfället. I de finländska åtgärderna betonas därför att banksystemet i så stor omfattning som möjligt ska klara sig på egen hand och utan onödigt statligt stöd. Samtidigt stödjer man dock av säkerhetsskäl framför allt 
långfristig finansiering av bankerna och främjande av soliditeten, och betonar att statsstödet ska ha tillräcklig vederlagskaraktär. Samtliga statliga stödformer kommer att vara förknippade med villkor i fråga om bankernas belöningssystem.

Som praktiska åtgärder föreslås att staten skulle börja bevilja garantier för finländska bankers medelsanskaffning utan garanti med maturiteter från tre månader till fem år. Garantier som söks frivilligt ska begränsas på flera olika sätt bl.a. så att användningen av garantier inte kan växa orimligt. Systemet föreslås vara i kraft preliminärt till slutet av 2009, men statsrådet ska bedöma i april 2009 om det är ändamålsenligt att bevilja garantier efter det. Maximibeloppet för garantierna ska då vara högst 50 miljarder euro, vilket är lite mera än beloppet för bankernas emitterade bankcertifikat och de masskuldebrev som förfaller före slutet av nästa år. Förutom maximibeloppet kan garantierna även begränsas för enskilda bankers del.

\subsection{Den ekonomiska utvecklingen}

Den långvariga kraftiga ekonomiska tillväxten I Finland har mattats av, och konjunkturnedgången började på tröskeln till sommaren. Utvecklingen för i år är dock tudelad, eftersom det goda sysselsättningsläget fortsätter till slutet av året. Den överraskat kraftiga uppgången i konsumentpriserna och finansmarknadernas turbulens har gjort att hushållens förtroende har minskat dramatiskt, något som i kombination med den höga skuldsättningen kan minska konsumtionen på ett svårförutsägbart sätt. Den försämrade efterfrågan stärks dock av nästa års skattelättnader som stöder konsumtionen. Den höjda kostnadsnivån försvårar företagens verksamhet och investeringsökningen avstannar nästa år.

Osäkerheterna i de ekonomiska utsikterna inom världsekonomin har ökat och världsekonomins tillväxttakt kommer att avta ännu nästa år. Konjunkturerna försämras snabbt också i Finland, och hela årets bruttonationalprodukt uppskattas öka med 2,8 \%. Internationellt sett är tillväxten fortfarande stark, men den baserar sig i första hand på industrins, exklusive skogsindustrin, byggandets och inrikeshandelns starka tillväxt under årets första hälft. Under den senare hälften av året är tillväxten liten, och för nästa år förutspås en tillväxt på blott 1,8 \%. Det finns dock risk för att tillväxten avtar ännu snabbare, framför allt i slutet av året. I detta avseende beror det mycket på de internationella finansmarknadernas utveckling.

Efterfrågan på arbetskraft tilltog mycket snabbt i fjol för tredje året i följd; åren 2005-2007 ökade antalet arbetsplatser med sammanlagt över 125000 och antalet lediga arbetsplatser var rekordstort. Antalet sysselsatta ökar även 2008 med cirka 40000 personer trots konjunkturförsämringen. Sysselsättningsgraden stiger till 70,6 \% och arbetslöshetsgraden 
sjunker till 6,2 \%. Efter flera år med starka arbetsmarknader ser utsikterna nu sämre ut. Sysselsättningen väntas bli oförändrad 2009, men arbetslöshetsgraden stiger inte, eftersom utbudet på arbetskraft sjunker.

Efter flera lugna år tilltog inflationen kännbart genast i början av året, och under hela året överstiger prisnivån fjolårets nivå med drygt 4 \%. Priserna på framför allt mat och bränsle har stigit kännbart. Dessutom har lönehöjningarna, som varit större än under tidigare år, och vissa ändringar i skatte- och avgiftsgrunderna höjt priserna. Nästa år uppskattas inflationen avta till 2,8 \%, när svagare efterfrågeläget och fallande importerade energipriser dämpas inflationen. Löntagarnas förtjänstnivåindex beräknas 2008 stiga med i medeltal 5,5 \% från föregående år och även nästa år med 5 \%.

Hushållens konsumtion har fortsatt att växa starkt och ökar i år med $3 \%$. De disponibla inkomsterna ökar i år tack vare den förbättrade sysselsättningen och lönehöjningarna, men inflationen äter upp en avsevärd del av den ökade köpkraften. Köpkraften ökar med endast 21/2\%. Skattelättnaderna 2009 ökar hushållens inkomster med drygt en procentenhet. Eftersom även inflationen avtar, ökar hushållens disponibla realinkomster mera än i år, med 31/2\%, trots att sysselsättningen inte längre förbättras. Hushållens sparkvot har försämrats de senaste åren och skuldsatt ökats i rask takt, och risken är att under de nuvarande omständigheterna konsumtionen växer långsammare än prognostiserats.

Investeringarna ökar med ungefär $4 \%$ i år, eftersom företagen fortsätter att investera starkt i såväl byggnader som maskiner och anordningar. Utsikterna för nästa år är osäkrare och efterfrågan på bostäder har redan avtagit på grund av bl.a. de stigande låneräntorna, de höga bostadspriserna samt osäkerheten om konjunkturerna.

Exportvolymen ökade i fjol med $8 \%$. Den totala exportökningen berodde på att tjänsteexporten ökade med $16 \%$, men också varuexporten ökade med $61 \frac{1}{2} \%$. Exporten av maskiner och båtar var särskilt livlig. Utrikeshandeln fortsatte att växa bra i början av året, men under den senare hälften av året avtar exportökningen och stannar för hela årets del kring 31/2\%. Nästa år fortsätter exportökningen att avta. Metallindustrin förblir lokomotivet i tillväxten medan skogsexporten krymper. I år sjunker överskottet i bytesbalansen i förhållande till totalproduktionen med $1 \frac{1}{2}$ procentenhet från i fjol och blir $4 \%$, och nästa år kring $3 \%$.

Ökningen av industriproduktionen under den första hälften av året har understötts av nytto- och exportlandsstrukturen inom produktionen och exporten. Skogsindustriproduktionen krymper och branschens svårigheter ökar ytterligare nästa år. År 2008 mer än halveras industriproduktionens tillväxttakt jämfört med fjolårets höga nivå till 31/2 \% och nästa år till 21/2\%. Volymmässigt ökade byggandet i fjol med $7 \%$ och tillväxten inom byggandet har fortsatt att ligga på den övre gränsen för produktionsmöjligheterna i början av året. Konjunkturläget för byggandet försämras nästa år. Inrikeshandelns försäljning fortsatte att öka starkt i början av året men farten har saktat under sommaren. 
Arbetets produktivitet förbättrades i fjol med 2,9 \%, något långsammare än föregående år, men $1 / 2$ procentenhet snabbare än under de tio senaste åren i genomsnitt. I år och nästa år sjunker tillväxttakten för arbetets produktivitet under den genomsnittliga nivån till cirka $2 \%$. Orsaken är i första hand att ekonomin står in för en konjunkturnedgång.

Fabriksindustrins kostnadskonkurrensförmåga förbättrades i fjol och var inom hela fabriksindustrin i medeltal 40 \% bättre än det långsiktiga medeltalet (1970-2004). Inom den andra industrin än den elektroniska industrin började konkurrenskraften dock försämras på nytt efter föregående års svaga förbättring och var bara ungefär 5 \% bättre än det långsiktiga medeltalet. I och med att arbetskostnaderna börjat öka snabbare och produktivitetsutvecklingen avta försämras fabriksindustrins konkurrenskraft i år inom de flesta sektorer. Utvecklingsbilden är densamma också nästa år.

\subsection{Utsikterna på medellång sikt}

På medellång sikt utgör de ökade utbudsbegränsningarna inom ekonomin, i synnerhet det minskade utbudet på arbetskraft när befolkningen åldras, ett allt större hinder för ekonomisk tillväxt. Befolkningen i arbetsför ålder börjar minska i slutet av årtiondet, och antalet 15-64-åringar förutspås minska med över 100000 personer fram till 2015. Produktivitetsökningen förväntas minska på medellång sikt till cirka $2 \%$ när antalet arbetsplatser minskar inom sådan industri där produktiviteten är högre och öka inom servicebranscherna där produktiviteten är lägre.

Tabell 3.1 Nyckeltal för Finlands ekonomi. Procentuell förändring. ${ }^{1)}$

\begin{tabular}{|c|c|c|c|c|}
\hline & Mrd. euro 2007 & 2007 & 2008 & 2009 \\
\hline \multicolumn{5}{|l|}{ Fasta priser } \\
\hline Hushållens konsumtionsutgifter (=privata) & 91 & 3,2 & 3,0 & 2,8 \\
\hline Offentliga konsumtionsutgifter & 38 & 1,3 & 1,6 & 1,8 \\
\hline Fasta bruttoinvesteringar & 37 & 8,5 & 3,7 & 0,1 \\
\hline Näringsliv & 23 & 12,3 & 7,6 & 0,8 \\
\hline Bostäder & 10 & 0,1 & $-3,0$ & $-1,0$ \\
\hline Myndigheter & 5 & 9,4 & 0,9 & $-1,1$ \\
\hline Lagerinvesteringar $^{2)}$ & 4 & & & \\
\hline Total inhemsk efterfrågan & 165 & 3,6 & 2,7 & 2 \\
\hline Export & 82 & 8,2 & 3,4 & 1,9 \\
\hline Import & 73 & 6,6 & 3,0 & 2,2 \\
\hline Bruttonationalprodukt & 180 & 4,5 & 2,8 & 1,8 \\
\hline Sysselsättning, personer & . & 2,0 & 1,6 & 0,1 \\
\hline Arbetslöshet (\% av arbetskraften) & . & 6,9 & 6,2 & 5,9 \\
\hline Konsumtionsprisindex & $\ldots$ & 2,5 & 4,1 & 2,8 \\
\hline Lön & $\ldots$ & 3,4 & 5,5 & 5 \\
\hline Effektiv valutakurs $^{4}$ & . & & & \\
\hline Bytesförhållande & . & $-1,4$ & $-2,8$ & $-1,3$ \\
\hline Bytesbalans (\% av BNP) & $\ldots$ & 5,3 & 3,9 & 2,8 \\
\hline 3-månaders penningmarknadsränta (nivå) & . & 4,3 & 5,0 & 4,7 \\
\hline
\end{tabular}

1) Beräknat i fasta priser, basår 2000. 2) Förändring i \% av föregående års BNP. 3) Löneindex. 4) Positivt tal innebär depreciering. Källor: Statistikcentralen och Finansministeriets ekonomiska avdelning (september 2008) 


\section{Island}

For 2008, a GDP growth of 1.7 per cent was expected in the Ministry's September forecast, but due to the recent turmoil in the financial market economic growth is expected to be somewhat less than that, but still on the positive side due to strong exports growth. National expenditure is, at present, seen to decline by more than before due to a considerable decline in private consumption and investment. GDP is forecast to decline in 2009 as national expenditure declines substantially due to declining private consumption and investment but the decline in investment is due to substantial decrease in general business sector and residential construction.

The latest national accounts statistics for the second quarter of this year indicate that a sharp reversal has begun in the economy with a contraction in both private consumption and investment along with a rapidly declining trade and services deficit. Following the sharp increase in private consumption in the first quarter of this year, it declined in the second quarter, following the decline in the exchange rate that increased inflation and reduced real disposable income. The decline in private consumption is expected to continue for the remainder of the year. Real disposable income per capita is forecast to decline by circa 5 per cent, asset prices are expected to decline also, and the access to credit will be limited.

Total investment was forecast to contract by 12.8 per cent in the September forecast but now the investment is expected to decline by a much larger figure. Business and housing investment are contracting sharply but public investment is, on the other hand, increasing. The expected decline in business investment is in part due to the completion of energyintensive investment activity. This contraction is partly offset by the construction of an aluminium oxide plant near Akureyri, an aluminium plant at Helguvík and an expansion of the Icelandic Alloys plant at Grundartangi. Prospects for housing investment have deteriorated sharply in the course of this year. At present, it is expected that housing investment will contract substantially this year which is reflected in a sharp decline in real property transactions, a large stock of unsold new housing units, and a limited access to housing credits at costlier terms.

Forecasts on the current account have varied widely this year. The deficits on goods and services was 10.5 per cent of GDP in 2007 and is expected to shrink considerably in 2008, mostly due to a sharp increase in aluminium exports and a further contraction in imports. The balance on factor income has on the other hand deteriorated. The latest figures for the second quarter of this year show that the deficit on the factor income account has increased to previously unknown highs. The low exchange rate increases the service burden on foreign debt in ISK terms which in 
turn is reflected in the adverse development of the factor account balance. Most, however, can be attributed to declining stock and asset prices in international markets. It is very uncertain to what extent the factor account reflects actual developments. Following the expansion of Icelandic companies abroad over the past several years, it has become increasingly difficult to value Icelandic assets abroad and their associated income flows. The adverse development of factor income offsets some of the improvement in the goods and services account. At present, and due to latest development, is it to early to re-estimate the balance of income account for 2008 and therefore the current account balance but the economy is in process of rapidly restoring its external balance.

The Central Bank policy rate currently stands at 12 per cent after the bank lowered the rate in October, as many households and businesses are now in danger of heading into bankruptcy. Before that the rate had increased continually since 2004. Over this period, the economy has been going through a vigorous expansion, and inflation has exceeded the Central Bank inflation target, of 2.5 per cent, calling for monetary restraint policy. But despite the monetary restraint applied in recent years, inflation has proven persistent. Conditions in international financial markets have had a profound impact on the Icelandic economy in recent years. The supply of low-cost credit has been abundant. Both households and businesses could borrow in foreign currency at lower interest rates than in ISK, thus to some extent obstructing the efforts of the Central Bank to pursue its policy. Once international financial markets turned around to their current credit crunch along with a vastly increasing CDS spread, the access to foreign borrowing by households and businesses became limited. These difficulties led to a sharp decline in the exchange rate in March 2008, in turn causing an inflation spurt that called for further monetary measures to prevent inflationary expectations from getting further away from the inflation target and necessitating more policy rate increases. In the September forecast, the Ministry assumed that the rates would remain unchanged for the remainder of 2008 but now it has become essential that the Central Bank will be able to decrease their rates further. But to prevent additional inflation increase the labour unions must accept modest nominal wages increases next year to prevent any wage-inflation spiral to occur.

Inflation reached an annual rate of 14 per cent in September 2008, the highest rate since 1990. At first, inflation could largely be attributed to domestic demand pressures that were reflected in rising housing prices and wages at the same time as unemployment was declining. But the reasons can also be attributed to a number of other causes, such as extensive energy-related investment projects and more liberal housing mortgage loans. The current inflation upturn began accelerating in March with the sharp decline in the exchange rate and higher import prices. The elements impacting upon inflation have changed in recent months. The tur- 
naround in the housing market has resulted in stagnating nominal housing prices. By now, the housing component is reducing inflation but import items are instead leading the increases in the CPI. In the September forecast 11.5 per cent average inflation was predicted in 2008 but at present inflation this year is expected to be slightly higher than that. In the beginning of next year inflation could still be high but later in the year it is expected to subside quickly as the exchange rate strengthens again.

When the September forecast was made the exchange rate had declined by close to 33 per cent from the beginning of the year. The general opinion of market participants was that the exchange rate would decline as the economy slowed down. As it turned out, the rate dropped faster and far further than expected immediately in March because of the turbulence in the international financial markets. In recent weeks the exchange rate has slumped. The index exceeded 200 points in the beginning of October and on the $7^{\text {th }}$. the Central Bank tried to fix the rate at proximately 175 points. But the Central Banks effort to stabilize the exchange rate failed and after the rate floated again the index fell to 230 points. In the September forecast the Ministry estimated the average index for 2008 at 148.9 but that assumption has to be re-vised. At present, the average index so far this year is 153 . The exchange rate has currently been fixed again at proximately 200 points but this time with currency restrictions. This prevents the exchange rate from declining further and temper the outflow of foreign currency but obviously it is a short-term solution and as soon as the domestic financial market stabilizes and the Central Bank increases its foreign currency reserves the exchange rate is expected float again. This could have a short-term increased cost-effect for many households and businesses if the exchange rate depreciates further but when looking ahead and into next year the exchange rate is expected to strengthen following increased foreign reserves and a positive external balance. It is not unlikely that at first the exchange rate will be given the change to float and fluctuate within certain confidence limits and the currency restriction will therefore be eliminated in steps. It would be a similar arrangement and was used when the ISK was floated in 2001.

There has been a very little unemployment in Iceland in recent years. In 2007, on average 1 per cent of the labour force was registered unemployed. This year, on the other hand, the rate has moved upward slightly, 1.3 per cent in September and with recent substantial lay-offs in the financial sector the rate will increase this year. In 2009, unemployment will increase further and above NAIRU, which is a proximately 3 per cent, but in the September forecast it was predicted that unemployment would be 2.7 per cent. But as many businesses are expected to go bankrupt next year unemployment is bound to increase but the Icelandic labour market is flexible and next year net out-migration is expected to increase considerably and their are already signs of increasing demand for further education. Wages have increased substantially during recent years. This year, 
however, inflation outstrips nominal wages increases leading to the prospect of lower real wages and according to the September forecast real disposable income per capita was expected to decrease by 4.9 per cent in 2008.

The Treasury surplus amounted to 4 per cent of GDP in 2007, slightly less than in 2006. The Treasury has yielded a surplus for the past four years which has been used to repay Treasury debt. For the first time the Treasury equity balance was positive at the end of 2007. But the decline in domestic demand will have a substantial impact on Treasury revenue in 2008 and the expenditure side will also be affected by latest developments. At present, it is too early to re-estimate the Treasury account deficit in 2008. 


\section{Norge}

\subsection{Den økonomiske politikken}

Den norske regjeringen vil føre en økonomisk politikk som legger til rette for arbeid til alle, fortsatt økonomisk vekst, en bærekraftig utvikling, en mer rettferdig fordeling og styrking av velferdsordningene. For å nå disse målene må de ulike delene av den økonomiske politikken virke sammen.

Finanspolitikken er lagt opp med utgangspunkt i retningslinjer som innebærer at petroleumsinntektene gradvis fases inn i norsk økonomi, om lag i takt med utviklingen i forventet realavkastning av Statens pensjonsfond - Utland (handlingsregelen). Budsjettpolitikken er dermed gitt en mellomlangsiktig forankring. Samtidig understreker retningslinjene at hensynet til en stabil økonomisk utvikling skal tillegges betydelig vekt $\mathrm{i}$ den løpende utformingen av budsjettpolitikken.

Pengepolitikken skal sikte mot stabilitet i den norske krones verdi, nasjonalt og i forhold til Norges handelspartnere. Den operative gjennomføringen av pengepolitikken skal rettes inn mot lav og stabil inflasjon, definert som en årsvekst i konsumprisene som over tid er nær 2,5 pst. Av forskriften følger det at pengepolitikken skal bidra til å stabilisere utviklingen i produksjon og sysselsetting og til stabile forventninger om valutakursutviklingen. Budsjett- og pengepolitikken må virke sammen for å bidra til en balansert utvikling i norsk økonomi.

Regjeringen legger opp til å holde bruken av petroleumsinntekter på et nivå som understøtter en fortsatt balansert utvikling i norsk økonomi, i overensstemmelse med de rammer handlingsregelen setter. De siste fire årene har norsk økonomi vært inne i den sterkeste konjunkturoppgangen siden tidlig på 1950-tallet. Etter årsskiftet har imidlertid både produksjon og etterspørsel økt klart saktere. I lys av avdempingen av veksten i norsk økonomi og usikre utsikter for verdensøkonomien legger Regjeringen opp til et strukturelt, oljekorrigert underskudd på 92 mrd. kroner neste år. Dette er på linje med anslaget for forventet realavkastning av Statens pensjonsfond - Utland i 2009, etter at bruken av oljeinntekter har ligget under denne 4-prosentbanen de siste tre årene. Det strukturelle underskuddet øker med om lag 14 mrd. kroner fra 2008 til 2009. Målt som andel av trend-BNP for Fastlands-Norge tilsvarer dette en økning på 0,7 prosentpoeng. Budsjettet bidrar dermed til å øke etterspørselen i norsk økonomi neste år. 


\subsection{Den økonomiske utviklingen}

Norsk økonomi er inne i en kraftig høykonjunktur etter fire år med historisk høy vekst. Fra 2003 til 2007 økte BNP for Fastlands-Norge med hele 5 pst. per år i gjennomsnitt. Høy inntektsvekst og flere år med lave renter ga en markert oppgang i husholdningenes etterspørsel gjennom perioden, samtidig som veksten i næringslivsinvesteringene var sterk. I tillegg bidro et kraftig oppsving i verdensøkonomien til høy eksportvekst. Oppgangen i fastlandsøkonomien førte til en rekordhøy vekst i sysselsettingen, og arbeidsledigheten falt til det laveste nivået på 20 år. Etter hvert har tilstrammingen i arbeidsmarkedet gitt tiltakende lønns- og prisvekst, og Norges Bank satte opp styringsrenten fra 13/4 pst. sommeren 2005 til 53/4 pst. sommeren 2008.

Både produksjon og etterspørsel har økt klart saktere etter årsskiftet enn i de siste årene. Høyere rente har bidratt til nedgang i boliginvesteringene, og veksten i privat konsum har avtatt markert. Samtidig er veksten i eksporten av tradisjonelle varer nå svakere. Også i tiden framover ligger det an til en mer moderat vekst i fastlandsøkonomien enn det vi har sett de siste årene. Den samlede etterspørselen fra oljevirksomheten ventes å gi om lag like sterke etterspørselsimpulser i år og neste år som gjennom konjunkturoppgangen de siste årene. Som følge av tilbakeslaget i OECD-området ligger det derimot an til relativt svake vekstimpulser fra den tradisjonelle vareeksporten framover, og foretaksinvesteringene $\mathrm{i}$ Fastlands-Norge ventes å falle noe i 2009. Også veksten i husholdningenes forbruk ventes å dempe seg av, fra 5 pst. som gjennomsnitt for de foregående fire årene til under $2 \frac{1}{2} 2$ pst. for 2008 og 2009 sett under ett. Etterspørselsimpulsene fra finanspolitikken ventes på den annen side å bli noe sterkere i år og neste år enn i de foregående årene. I Nasjonalbudsjettet 2009 anslås veksten i BNP for Fastlands-Norge å avta fra 6,2 pst. i fjor til vel 3 pst. i år og knapt 2 pst. neste år. Også i årene 2010-2012 er det lagt til grunn relativt moderat vekst i norsk økonomi.

Etter framleggelsen av Nasjonalbudsjettet 2009 har uroen i finansmarkedene tiltatt ytterligere, og usikkerheten om den videre økonomiske utviklingen blitt større. Hovedindeksen på Oslo Børs har falt markert, og det har vært en betydelig svekkelse av den norske kronen mot euro og amerikanske dollar. Norges Bank senket styringsrenten med $1 / 2$ prosentpoeng, til 51/4 prosentpoeng, den 15. oktober.

Det norske banksystemet har hatt god inntjening og moderate tap. Soliditeten er god. Den alminnelige tillitssvikten i det internasjonale kredittmarkedet og problemene i det internasjonale interbankmarkedet har imidlertid smittet over også på det norske penge- og kredittmarkedet. Risikopåslagene har økt og tilgangen på finansiering for norske banker er vanskelig. Norske myndigheter har på denne bakgrunn iverksatt tiltak som kan bidra til å bedre lånemuligheten for norske banker. Norges Bank har tilført mer likviditet enn normalt ved hjelp av sine vanlige likviditets- 
politiske virkemiddel, F-lån. Mens løpetiden på F-lån normalt har vært opp til om lag en uke, har Norges Bank den siste tiden også tilbudt F-lån med lengre løpetid samt lempet på kravet til verdipapirer bankene kan brukes som sikkerhet for lån i Norges Bank. Norges Bank har videre inngått valutaswapper, både ved at bankene for en periode er blitt tilført kroner mot oppgjør i dollar eller i euro, og Norges Bank har tilført dollar direkte til markedet. Det er inngått kredittavtale med den amerikanske sentralbanken som stiller dollar til rådighet for Norges Bank.

Regjeringen vil i tillegg tilby banker i Norge å få bytte boliglånsobligasjoner med statsobligasjoner. Staten vil legge ut nye statsobligasjoner for inntil 350 milliarder kroner for dette formålet. I tillegg vil Norges Bank gi F-lån med to års løpetid som særlig er rettet inn mot de mindre bankene. Disse tiltakene har to siktemål. For det første kan bankene få en bedre struktur på sin gjeld med en større andel langsiktig finansiering. De kan selge statspapirene og nedbetale kortsiktig gjeld, eller de kan bruke statspapirene som sikkerhet for nye langsiktige lån. For det andre kan bankene benytte statspapirene som sikkerhet for lån seg imellom, slik at vi forhåpentligvis etter hvert kan få et fungerende marked bankene imellom basert på sikrede lån i norske kroner.

Siden omslaget i norsk økonomi våren 2003 har rundt 300000 flere personer kommet i jobb. Selv om årsveksten i sysselsettingen fortsatt er høy, tyder sesongjusterte tall på en klar avdemping av sysselsettingsveksten den siste tiden. Lavere vekst i fastlandsøkonomien tilsier at det er grunn til å vente en mer moderat vekst i sysselsettingen også i tiden framover. I Nasjonalbudsjettet 2009 legges det til grunn at antall sysselsatte vil øke med 70000 personer fra 2007 til 2008. I 2009 er det lagt til grunn en vekst på 10000 personer.

Oppgangen i etterspørselen etter arbeidskraft de siste årene har til dels blitt dekket av arbeidssøkere fra de nye EØS-landene. Ifølge Statistisk sentralbyrå stod arbeidsinnvandringen for drøyt $1 / 4$ av sysselsettingsveksten i 2007. I tillegg har yrkesdeltakelsen blant nordmenn økt markert. Lavere etterspørsel etter arbeidskraft i bygg og anlegg og deler av industrien kan føre til at arbeidsinnvandringen vil avta fra de høye nivåene vi har sett de siste årene. Erfaringsmessig vil yrkesdeltakelsen blant nordmenn gå ned når konjunktursituasjonen svekkes, særlig blant ungdom. Usikkerheten knyttet til utviklingen i arbeidsstyrken er imidlertid stor. Arbeidsledigheten har flatet ut på rundt $2 \frac{1}{2} 2$ pst. av arbeidsstyrken det siste året. Lavere vekst i etterspørselen etter arbeidskraft trekker i retning av en forsiktig økning i arbeidsledigheten framover. I Nasjonalbudsjettet 2009 er ledigheten anslått til 21/2 pst. av arbeidsstyrken i 2008 og 23/4 pst. i 2009.

Det stramme arbeidsmarkedet har bidratt til at lønnsveksten er blitt omtrent like høy som under høykonjunkturen på slutten av 1990-tallet. På bakgrunn av resultatene i lønnsoppgjørene anslås den gjennomsnittlige årslønnsveksten i Nasjonalbudsjettet 2009 til 6 pst. i 2008. Avdempet 
vekst i norsk økonomi i 2008 og 2009 tilsier at knappheten på arbeidskraft etter hvert vil avta, og at lønnsveksten vil gå noe ned neste år. Lønnsveksten i 2009 anslås i Nasjonalbudsjettet 2009 til 5 pst.

Høy kapasitetsutnyttelse og økt lønnsvekst har bidratt til at den underliggende prisstigningen har tatt seg klart opp det siste året. Konsumprisene justert for avgiftsendringer og utenom energivarer (KPI-JAE) har hittil i år økt med 2,4 pst. sammenliknet med samme periode i fjor, og tolvmånedersveksten var 3,1 pst i september. Til sammenlikning økte KPI-JAE med 1,4 pst. fra 2006 til 2007. Andre indikatorer for den underliggende prisstigningen viser en enda høyere prisvekst i år. Lavere lønnsvekst og kapasitetsutnyttelse kan bidra til at den underliggende prisveksten avtar noe gjennom 2009. I Nasjonalbudsjettet 2009 anslås KPI-JAE å øke med $2^{1 / 2}$ pst. i 2008 og 23/4 pst. i 2009. Utviklingen i energiprisene bidrar nå til høy vekst i den samlede konsumprisindeksen (KPI), etter å ha bidratt til lav konsumprisvekst i 2007. Fra september i fjor til september i år økte KPI med 5,3 pst. Det legges i Nasjonalbudsjettet 2009 til grunn at KPI øker med 33/4 pst. i 2008 og 3 pst. i 2009, opp fra en vekst på 0,8 pst. i 2007.

\subsection{Utsiktene på mellomlang sikt}

Fra 2003 til 2007 økte BNP for Fastlands-Norge med hele 5 pst. i gjennomsnitt per år, 2 prosentpoeng over gjennomsnittet for perioden 19702007. Den sterke BNP-veksten de siste årene har ikke hatt noe motstykke i unormalt høy produktivitetsvekst, men i en svært kraftig oppgang i arbeidsinnsatsen.

Yrkesdeltakelsen ligger nå på et rekordhøyt nivå, og en normalisering av konjunktursituasjonen på mellomlang sikt kan dermed trekke i retning av en noe mindre økning i arbeidsinnsatsen enn det som følger av den historiske veksten i arbeidsstyrken. Ofte er produktivitetsveksten relativt lav rundt en konjunkturtopp, og konjunktursituasjonen kan dermed tilsi en noe lavere produktivitetsvekst enn det historiske gjennomsnittet. Med en produktivitetsvekst på 11/2-2 pst. kan veksten i produksjonskapasiteten i Fastlands-Norge i årene 2010-2012 anslås til 2-21/2 pst. per år.

Også utviklingen på etterspørselssiden trekker i retning av en relativt moderat vekst i fastlandsøkonomien i årene 2010-2012. Det er lagt til grunn at en økning i husholdningenes sparing, fra et svært lavt nivå, gir moderat vekst i det private konsumet. Også petroleumsinvesteringene kan avta noe i årene 2010-2012. Videre er det i de anslagene som gjengis her, teknisk lagt til grunn om lag samme gjennomsnittlige etterspørselsimpuls fra budsjettpolitikken i årene 2010-2012, som i perioden etter innføringen av handlingsregelen.

Den anslåtte veksten i fastlandsøkonomien i årene 2010-2012 er noe lavere enn den beregnede trendveksten. Dette er ventet å dempe presset i 
arbeidsmarkedet, og å bidra til en svak oppgang i arbeidsledigheten. Ledigheten holder seg likevel under gjennomsnittet for de siste 25 årene.

Tabell 5.1 Nøkkeltall for norsk økonomi. Prosentvis endring fra året før ${ }^{1)}$

\begin{tabular}{|c|c|c|c|c|}
\hline & \multicolumn{4}{|c|}{ Mrd kroner } \\
\hline & 2007 & 2007 & 2008 & 2009 \\
\hline \multicolumn{5}{|l|}{ Faste priser } \\
\hline Privat konsum & 946,1 & 6,4 & 2,3 & 2,5 \\
\hline Offentlig konsum & 449,3 & 3,6 & 3,8 & 3,4 \\
\hline Bruttoinvesteringer i fast kapital & 473,1 & 9,3 & 4,6 & $-0,3$ \\
\hline Herav:Oljeutvinning og rørtransport & 107,9 & 5,5 & 11,0 & 5,0 \\
\hline Bedrifter i Fastlands-Norge & 168,0 & 12,5 & 7,9 & $-2,4$ \\
\hline Boliger & 105,3 & 5,5 & $-8,5$ & $-2,0$ \\
\hline Offentlig forvaltning & 69,2 & 7,8 & 6,2 & 2,7 \\
\hline Lagerendring $^{2)}$ & 51,9 & $-0,3$ & 0,0 & 0,0 \\
\hline Total innenlandsk etterspørsel & 1920,4 & 5,8 & 3,1 & 2,0 \\
\hline $\begin{array}{l}\text { Herav: Etterspørsel fra Fastlands- } \\
\text { Norge (utenom lagerendring) }\end{array}$ & 1737,9 & 6,2 & 2,7 & 2,0 \\
\hline Eksport & 1042,7 & 2,8 & 2,2 & 2,5 \\
\hline Herav: Råolje og naturgass & 479,9 & $-2,8$ & $-1,5$ & 2,6 \\
\hline Tradisjonelle varer & 302,4 & 9,0 & 5,9 & 1,8 \\
\hline Import & 686,3 & 8,7 & 5,3 & 1,8 \\
\hline Herav: Tradisjonelle varer & 450,7 & 8,1 & 5,5 & 1,9 \\
\hline Bruttonasjonalprodukt & 2276,8 & 3,7 & 2,0 & 2,3 \\
\hline Herav: Fastlands-Norge & 1714,6 & 6,2 & 3,1 & 1,9 \\
\hline \multicolumn{5}{|l|}{ Andre nøkkeltall: } \\
\hline Sysselsetting, personer & & 4,0 & 2,8 & 0,4 \\
\hline Arbeidsledighetsrate, AKU (nivå) & & 2,5 & $21 / 2$ & $23 / 4$ \\
\hline Konsumprisindeksen (KPI) & & 0,8 & $33 / 4$ & 3 \\
\hline Årslønn & & 5,4 & 6 & 5 \\
\hline \multicolumn{5}{|l|}{ Effektiv valutakurs (Konkurranse- } \\
\hline kursindeksen) $)^{3)}$ & & $-1,7$ & -3 & $2^{1 / 2}$ \\
\hline Bytteforholdet overfor utlandet, totalt & & $-2,2$ & 15,5 & $-7,4$ \\
\hline \multicolumn{5}{|l|}{ Bytteforholdet overfor utlandet, } \\
\hline tradisjonelle varer & & $-1,1$ & $-0,2$ & $-1,2$ \\
\hline Driftsbalansen (pst. av BNP) & & 15,4 & 20,5 & 16,6 \\
\hline Pengemarkedsrenter (3 mndr.) & & 5,0 & 6,5 & 6,5 \\
\hline
\end{tabular}

1) Beregnet i faste 2005-priser 2) 2) Endring i prosent av BNP.året før. 3) 3) Et positivt endringstall innebærer en svekkelse av norske koner. Kilder: Statistisk sentralbyrå og Finansdepartementet. 



\section{Sverige}

\subsection{Den ekonomiska politiken}

Sveriges offentliga finanser är fortsatt starka och utvecklingen lever väl upp till stabilitets- och tillväxtpaktens krav. Det av riksdagen beslutade målet för den offentliga sektorns finansiella sparande på 1 procent av BNP över konjunkturcykeln sätter ramarna för finanspolitiken. Överskottet åren 2000-2007 var i genomsnitt 1,4 procent av BNP och det bedöms i genomsnitt uppgå till 2,0 procent av BNP under perioden 2008-2011. Överskottsmålet har utformats med utgångspunkt från att de offentliga finanserna ska vara långsiktigt hållbara. Vidare ska fördelningen av resurser mellan generationerna vara jämn och ekonomin ska fungera effektivt.

Mot bakgrund av att de åldersrelaterade offentliga utgifterna framöver kommer att öka markant anser regeringen att överskottsmålet på $1 \%$ av BNP över en konjunkturcykel bör upprätthållas så länge det är nödvändigt för att de offentliga finanserna ska utvecklas på ett långsiktigt uthålligt sätt. När den nuvarande demografiska situationen med relativt stora generationer i arbetsför ålder förändras och andelen äldre ökar markant, kan det dock vara motiverat att justera nuvarande överskottsmål. Samtidigt visar såväl svenska som internationella erfarenheter att en finanspolitisk regim utan regler och mål inte är bra och skadar samhällsekonomin. Regeringen vill därför betona att finanspolitiken även fortsättningsvis ska omgärdas av tydliga mål och regler. Regeringen avser att även framgent låta finanspolitiken vägledas av ett mål för det finansiella sparandet.

De fleråriga utgiftstakets främsta uppgift är att ge förutsättningar att uppnå överskottsmålet. Utgiftstaket utgör ett viktigt budgetpolitiskt åtagande som främjar budgetdisciplinen och stärker trovärdigheten i den ekonomiska politiken genom att förhindra att tillfälliga inkomster används för att finansiera varaktiga utgifter. Utgiftstaket understryker även behovet av prioriteringar mellan olika utgifter och förebygger en utveckling där skatteuttaget stegvis måste höjas till följd av bristfällig utgiftskontroll. Regeringen avser att i de ekonomiska vårpropositionerna göra en bedömning av och redovisa ett lämpligt utgiftstak för 2011. Därmed säkerställs finanspolitikens medelfristiga perspektiv.

Riksbanken har preciserat ett explicit inflationsmål som innebär att den årliga förändringen av konsumentprisindex (KPI) ska vara 2 procent med ett toleransintervall på plus/minus 1 procentenhet. Penningpolitiken vägleds också av olika mått på "underliggande inflation”. Det finns inte något enskilt inflationsmått som vid varje given tidpunkt alltid visar vilken penningpolitik som behövs. Penningpolitiken verkar med eftersläp- 
ning och inriktas normalt på att inflationsmålet ska uppnås inom två år. Två-årshorisonten ger utrymme att ta hänsyn till utvecklingen i realekonomin.

\subsection{Den ekonomiska utvecklingen}

Efter flera år med hög tillväxt bromsar svensk ekonomi in. ${ }^{2}$ Den fortsatta internationella finansiella turbulensen bidrar till att förutsättningarna för hushållens konsumtion har försämrats betydligt. Den svenska börsen har gått ner kraftigt och inflationen är fortsatt hög, vilket håller tillbaka konsumtionsviljan. Den ökade osäkerheten på bostadsmarknaden dämpar dessutom hushållens konsumtion ytterligare. Samtidigt innebär den finanspolitiska stimulansen en ökning av den disponibla inkomsten. För 2008 och 2009 förväntas den försämrade omvärldskonjunkturen innebära att efterfrågan på svensk export avtar och att exportutvecklingen blir dämpad. Den kraftiga produktivitetsinbromsningen i Sverige under 2007 och inledningen av 2008 bidrar till ett ökat kostnadstryck, vilket gör det svårare för svenska företag att konkurrera på de internationella marknaderna. Efter fem år med stark och bred investeringsuppgång bromsar investeringstillväxten in. Kapacitetsbrist utgör inte längre ett stort problem för företagen och den finansiella oron har lett till stramare kreditvillkor, vilket gör att företagen skjuter investeringar på framtiden. Under 2008 bedöms industriföretagen anpassa sina lager till den svagare efterfrågeutvecklingen, vilket innebär att lagerinvesteringarna väntas dra ned BNP-tillväxten.

Höstens finansiella kris innebär att den framtida makroekonomiska utvecklingen för närvarande är osedvanligt svårbedömd. Först och främst är den finansiella krisens intensitet, persistens och omfattning fortfarande osäker. Därtill är kanalerna mellan den finansiella sektorn och den reala ekonomin relativt outforskade. Höstens utveckling riskerar dock leda till att omvärldens efterfrågan på svenska exportprodukter minskar mer än väntat och att konsumtions- och investeringsviljan dämpas ytterligare hos svenska hushåll och företag.

De svenska bankerna har solida balansräkningar efter flera år med goda vinster. Finansinspektionen har konkluderat att de fyra stora bankerna på den svenska marknaden kan klara stora kreditförluster, exempelvis om situationen blir allvarlig i Baltikum till följd av recession. Även i Sverige har dock oro över kreditrisker lett till en brist på tillit som påverkat interbankmarknaden, med likviditetsbrist, högre räntekostnader och stramare kreditvillkor som resultat. Under oktober sköt spreaden mellan interbankränta och statsobligationsränta, TED-spreaden, i höjden efter att efterfrågan på säkra statspapper ökade kraftigt samtidigt som interbankräntan fortsatte att stiga.

\footnotetext{
${ }^{2}$ I denna prognos har inte det ordinarie NR-utfallet för andra kvartalet 2008 beaktats.
} 
Riksgälden har ingripit genom att sälja statsskuldväxlar i extrainsatta auktioner och investerat i svenska bolåneobligationer. Förutom sitt deltagande i oktober månads samordnade sänkning av styrräntor i Europa och Nordamerika, har Riksbanken svarat bland annat genom att erbjuda ytterligare krediter, även med längre löptider än normalt. Den 23 oktober sänkte Riksbanken styrräntan med ytterligare 0,5 procentenheter.

Regeringen har lanserat en stabilitetsplan för Sverige som utgår från överenskommelsen i EU. I planen ingår ett garantiprogram på upp till 1500 miljarder kronor som, mot en avgift, låter solventa kreditinstitut få statlig garanti för sin upplåning. Inför framtida eventuella solvensproblem i svenska institut byggs en stabilitetsfond upp som samfinansieras av staten och kreditinstitut. Stabilitetsplanen medger att staten går in med stöd i form av kapitaltillskott genom köp av preferensaktier i institut som är viktiga för det finansiella systemet.

Arbetsmarknaden har visat en positiv utveckling under en längre tid. Men sedan slutet av 2007 har såväl antalet sysselsatta som antalet personer i arbetskraften börjat växa allt långsammare. Denna inbromsning fortsätter framöver och sysselsättningen väntas vara oförändrad 2009. Arbetskraften väntas däremot fortsätta öka framöver, både till följd av en ökande befolkning i arbetsför ålder men även som en effekt av genomförda reformer (bl.a. jobbskatteavdraget och reformerna inom sjukförsäkringen). Då arbetskraften fortsätter att öka samtidigt som sysselsättningen minskar, ökar arbetslösheten från 6,0 \% 2008 till 6,4 \% 2009. Till följd av genomförda reformer samt en svagare konjunktur fortsätter sjukfrånvaron att minska.

\subsection{Utsikterna på medellång sikt}

På längre sikt styrs BNP i högre grad av hur ekonomins utbudssida utvecklas. Utbudssidan bedöms utvecklas starkt framöver och bidrar till att förutsättningarna är goda för en stark tillväxt när efterfrågan väl tar fart. Både 2008 och 2009 bedöms resursutnyttjandet i ekonomin vara lägre än normalt. Ett lågt resursutnyttjande i ekonomin leder till en svagare löne- och prisutveckling. I kombination med en återhämtning i produktivitetstillväxten 2009 bidrar det till ett lägre kostnadstryck de kommande åren. Den lägre ekonomiska aktiviteten och det sänkta kostnadstrycket bedöms leda till att Riksbanken fortsätter sänka räntan. Lägre räntor i kombination med en starkare internationell konjunktur ger förutsättningar för en god tillväxt 2010 och 2011. Trots att BNP-tillväxten tar fart 2010 sjunker sysselsättningen eftersom den stigande efterfrågan 2010 initialt bedöms mötas av en relativt stark produktivitetsåterhämtning. Först 2011 väntas antalet sysselsatta öka, eftersom företagen då bedöms ha behov av nyanställningar för att ha möjlighet att fortsätta expandera. Den minskade 
sysselsättningen leder till högre arbetslöshet 2010. När efterfrågan på arbetskraft tilltar sjunker dock arbetslösheten 2011.

Tabell 6.1 Nyckeltal för Sveriges ekonomi. Procentuell förändring ${ }^{1)}$

\begin{tabular}{|c|c|c|c|c|}
\hline & Mdr. kronor 2007 & 2007 & 2008 & 2009 \\
\hline \multicolumn{5}{|l|}{ Fasta priser } \\
\hline Hushållens konsumtionsutgifter & 1434 & 3,0 & 1,8 & 2,3 \\
\hline Offentliga konsumtionsutgifter & 797 & 1,1 & 0,4 & 0,9 \\
\hline Fasta bruttoinvesteringar & 582 & 8,0 & 3,0 & $-0,8$ \\
\hline Näringsliv, exkl. bostäder & 390 & 8,9 & 3,5 & $-0,1$ \\
\hline Bostäder & 103 & 8,7 & $-0,6$ & $-6,4$ \\
\hline Myndigheter & 89 & 3,3 & 4,9 & 2,4 \\
\hline Lagerinvesteringar $^{2)}$ & 24 & 0,7 & $-0,5$ & $-0,1$ \\
\hline Total inhemsk efterfrågan & 2836 & 4,2 & 1,1 & 1,2 \\
\hline Export & 1609 & 6,0 & 4,6 & 3,8 \\
\hline Import & 1375 & 9,6 & 4,3 & 4,1 \\
\hline Bruttonationalprodukt & 3071 & 2,7 & 1,5 & 1,3 \\
\hline Sysselsättning, personer & . & 2,4 & 1,2 & 0,0 \\
\hline Arbetslöshet (\% av arbetskraften) & . & 6,2 & 6,0 & 6,4 \\
\hline Konsumtionsprisindex & . & 2,2 & 3,8 & 2,4 \\
\hline Lön ${ }^{3)}$ & $\cdots$ & 3,3 & 4,7 & 4,4 \\
\hline Effektiv valutakurs ${ }^{4)}$ & $\cdots$ & 3,5 & 4,1 & 3,5 \\
\hline Bytesförhållande & . & 1,8 & $-1,4$ & 0,0 \\
\hline Bytesbalans (\% av BNP). & . & 8,5 & 8,3 & 8,4 \\
\hline 3-månaders penningmarknadsränta (nivå) & $\ldots$ & 3,5 & 4,1 & 3,5 \\
\hline
\end{tabular}

1) Beräknat i fasta priser, referensår 2007. 2) Förändring i \% av föregående års BNP. 3) Löneindex, procentuell förändring enligt Nationalräkenskapernas definition. 4) Positivt tal innebär depreciering. 